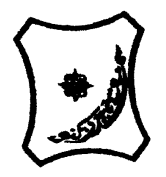

Bayero Journal of Pure and Applied Sciences, 8(1): 101 - 108

Received: September, 2014

Accepted: April, 2015

ISSN $2006-6996$

\title{
DETERMINANTS OF POVERTY AMONG BEE FARMERS: AN ANTIDOTE FOR APICULTURAL DEVELOPMENT IN KWARA STATE, NIGERIA
}

\author{
Oladimeji, Y. U., ${ }^{1}$ Ajao, A.M. and Abdulsalam, Z. \\ Department of Agricultural Economics and Rural Sociology, Faculty of Agriculture, Ahmadu Bello University, \\ P.M.B. 1044, Zaria, Kaduna State, Nigeria. \\ ${ }^{1}$ College of Pure and Applied Science, Department of Bioscience and Biotechnolgy, Kwara State University, \\ Malete, PMB 1533, Ilorin, Kwara State, Nigeria. \\ Correspondence author: yusuf.dimeji@yahoo.com; +2348032220000
}

\begin{abstract}
The study examined the poverty status of bee-farmers in two ecological zones of Kwara State, Nigeria with modern bee-keeping farmers as a case study. Primary data subjected to a pre-survey which involved structured questionnaire and interview schedule were administered using multistage random technique to selected 80 bee farmers in the two ecological zones. Sixty five percent of bee farmers earned at least $\$ 25,000$ per annum each and averaged $\$ 30,800$ from bee production. This shows positive contribution to bee household's welfare. Majority of the pooled farmers (75\%) had subsidiary occupations with average yearly off-farm income of $\$ 35,600$. This shows that the rural farmers have developed capacity to cope with increasing vulnerability associated with apicultural practices by diversification and migration. The result of logit regression revealed that years of experience; level of education; adjusted household size; number of hives; bee income and non-bee income were found to be significant in poverty determinants of bee farmers. The Foster-Greer-Thorbecke index analysis estimated a poverty line of $\$ 236.50$ (US\$1.48) per household head per day. The results revealed that improvement in level of training, amount of credit accessed and increasing number of hives invested were inversely related to poverty status of bee farmers. The results also showed prevalence of poverty among rural bee households that utilized open spaces for disposing their faeces, stream water for drinking and local lamp for lightening compared to bee farmers that utilized pit toilets, well water or boreholes and electricity respectively.
\end{abstract}

Keywords: Bee farmers, education, extension contact, poverty

\section{INTRODUCTION}

Agriculture is an important economic sector in Nigeria which maintain a steady contribution of $35 \%$ to $40 \%$ to total Gross Domestic Product (GDP) between 2008 and 2012 UUnited Nation Development Programme (UNDP), 2009 and Food and Agricultural Organisation (FAO), 2013\}. Among Africa countries, Nigeria is generally considered to have one the largest population of livestock, a sub-sector under agriculture. For example, the Resources Inventory and Management (RIM, 1992) estimated livestock population in Nigeria at 14 million cattle, 34.5 million goats, 22 million sheep, 82 million chickens, 32 million poultry, 3.5 million pigs, 1.7 million domesticated rabbits, 0.94 million donkeys and 0.29 million other equines. However, in spite of considerable work to capture inventory of livestock potential in Nigeria, there is no fact and figure that can indicate the quantities of honey produced and estimated demand in Nigeria like the above mentioned other livestock. Suffice to note that beekeeping or apiculture, which is one of the important livestock sub-sectors, contributes significantly to improvement of the livelihoods of the nation's population particularly in the rural area.

Nigeria has a high potential for apiculture, as the climate has diverse and rich vegetation, copious fauna, and abundant water resource, which are a good source of nectar and pollen for honeybee.
The potential resource are capable of supporting a large population of crops and livestock including honey bees, with about 214 billion $\mathrm{m}^{3}$ of surface water and $87 \mathrm{~km}^{3}$ of ground water (FAO, 2013; Oladimeji et al., 2014). Suffice to note also that honey bees play a crucial role in biodiversity conservation which implied a direct relationship with environmental protection. They are ubiquitous in plant ecosystem and are capable of adaptability to environmental changes. As the most efficient pollination, they increase the level of food productivity several folds. Honey generates enormous income to the farmers and apparently improved living standards besides their role in tradomedicine and raw material for industries. In addition, pollen which contains about $35 \%$ protein, and propolis and bee venom is also important products from beekeeping with enormous and diverse uses (Ajao and Oladimeji, 2013).

Problem Statement

Despite this large natural resource endowment and immense potential of honey production among the rural farming households in Kwara State and Nigeria as a whole, poverty and hunger remain critical developmental challenges. Apart from convincing evidence, which suggests that, the country belongs to the group of the lower-income countries, GNI per capita of \$US 2,069 in 2011 compared to the estimated world's per capita income of $\$ 10,082$, 
Bajopas Volume 8 Number 1 June, 2015

about $70 \%$ of Nigerian poor reside in rural areas and depend on agriculture for their subsistence \{World Bank, 2011; National Bureau of Statistics (NBS), 2013\}. Using selected world developmental indicators in 2011, the life expectancy at birth was 51.9 years, Human Development Index (HDI) values, 0.459 and Gini Index of 48.8 showing high level of income inequality in Nigeria (World Bank, 2011). This implies that there is a generalised high level of poverty in the country. It also shows the poverty incidence has risen from $27.2 \%$ (17.1 million people) in 1980 to 42.7\% (39.2 million) in 1992 and somersaulted to $69 \%$ (112.5 million) in 2010. The survey also revealed that the incidence of poverty is higher in rural compared to urban areas with the relative poverty being $72.2 \%$ and $61.8 \%$ respectively (NBS, 2013). This does not say much about the location specific, extent and determinants of poverty in the rural area.

Further, with the recognition by the Nigerian Government of the multi-sectored and multidimensional nature of poverty, a number of coordinated programmes and policies had been formulated to combat poverty in all its ramifications. Yet, the rural bee farmers have suffered from low access to various services such as education, good sanitation, health, and rural electrification, access to safe water, housing, credit, and lack of assets such as land and livestock which are strongly related to the rural poverty. Therefore, to achieve poverty reduction in Nigeria, it becomes necessary to empirically measure the poverty status and examine the determinants of poverty among the rural farming households.

A Foster-Greer-Thorbecke (FGT) index was used to measure the poverty status of the bee farming households in the study area. It is a co-efficient (a) reflecting different degrees of importance accorded to the depth of poverty and it ranges from 0 to 2 . A co-efficient of 0 implies the headcount ratio while 1 and 2 measured the poverty gaps and severity respectively (Foster et al., 1984). The need to investigate poverty and its determinants has also been justified by (Ravallion, 1998) who argued that 'a credible measure of poverty and its determinants can be a powerful instrument for focusing the attention of policy makers on the living conditions of the poor'. However, poverty in Nigeria is more of a rural phenomenon and is increasing unabated. Its incidence and severity are more in the agricultural sector than other sectors of the economy. There is

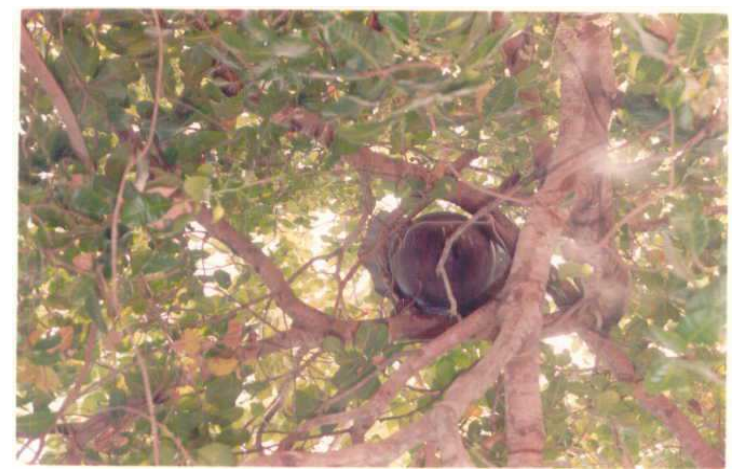

Figure 1: Traditional beekeeping hive however, scanty literature on bee farming households and poverty, and the particular disadvantages they might encounter. Understanding the factors underlying their persistent deprivation is important, when designing policies to meet their needs and improve their welfare. This study examined the effect of near absence of infrastructure on the living standard of bee farmers with respect to the poverty level. Specifically, it estimated the factors that determine the bee farmers' poverty level in Kwara State, Nigeria.

\section{RESEARCH METHODOLOGY}

\section{Study area and data collection}

The study was conducted in Kwara State, Nigeria. The State is located between latitude $7^{0} 45^{\prime}$ and $9^{\circ}$ $30^{\prime} \mathrm{N}$ and longitude $2^{\circ} 30^{\prime} \mathrm{E}$ and $6^{\circ} 25^{\prime} \mathrm{E}$ with a land mass covering about $32,500 \mathrm{sq} \mathrm{km}$, a total land size of 3,682,500 ha and 247,975 farm families in 2006 with majority living in rural areas. With an estimated population of about 2.4 million people \{National Population Commission, (NPC) 2006\}, the State's population and farm families were projected in 2014 to be about 3 million and 297, 078 respectively representing 3.2\% annual growth rate and an average density of 94 persons per sq. $\mathrm{km}$. The annual rainfall ranges from $800 \mathrm{~mm}$ to $1500 \mathrm{~mm}$ per annum while mean annual temperature is between $31.5^{\circ} \mathrm{C}$ and $35^{\circ} \mathrm{C}$ (Oladimeji and Abdulsalam, 2013). The State lies in two geo-ecological zones; the derived savanna which is characterized by woodland and the Guinea savanna which is characterized by tall grasses growing intermixed with deciduous trees making it one of the high potential areas for developing beekeeping in the region as well as in the country. The savannah is characterized by tall grasses intermixed with scattered trees. Economic trees found in the area includes Citrus sinensi, Parkia biglobosa, Butyrospermum parkii, Azadiracta indica, Mangifera indica, Acacia species and Anacardium occidentale. These species of trees provide forage for the bees. Suffice to note that West Africa is endowed with a rich variety of bees such as Apis mellifera (KWADP, 2008).

Majorly, the vast agriculture, horticulture and forest cover of Nigeria coupled with dominance of its majority of rural population on agriculture make beekeeping one of the most important potential village enterprise. Majority of the beekeepers in the State were using both traditional and improved beekeeping practices as differentiated in figures 1 and 2 below which were adapted from Ajao, (2012).



Figure 2: Modern beekeeping hive 


\section{Sampling procedure and sampling technique}

The entire rural bee households in Kwara State were the target population for the study. However, a multi-stage random sampling technique was employed. The first stage involved random selection of 3 Local Government Areas (LGAs) each from both guinea and derived savanna with exclusion of cosmopolitan LGAs. These were: Edu, Patigi, Moro (Guinea savanna ecozone) and Ifelodun, Irepodun, Offa (Derived savanna ecozone) areas of Kwara State, Nigeria. The second stage involved the random selection of one rural community from each LGA to make a total of 6 communities' viz. Lafiagi, Patigi, Bode-saadu (Guinea savanna); Buhari, Amberi-ajasse and Offa (derived savanna). Finally, a proportionate random selection of 80 bee farmers was done. Primary data subjected to a pre-survey using a structured questionnaire and interview schedule were used for this study.

\section{Analytical techniques}

To estimate the determinants of poverty among the bee farmers, binary dependent variable models provide a good framework. This study made used of logistic regression model to assess the factors that determines the bee farmers' poverty level. Poverty index was constructed to classify the bee farmers into poor and non-poor household using a poverty line. The relative poverty line that was used for this study is defined as the two-thirds of mean household income per adult equivalent. Household expenditure or income is considered as an adequate measure of household welfare in developing countries as it better able to capture household's consumption capabilities (Bogale et al., 2005). Accordingly, a household is considered as poor when household income or expenditure is insufficient to meet the food and other basic needs of all household members. Adult equivalent was generated from Organization for Economic Corporation and Development (OECD) Scale adopted by Etim and Ukoha, (2010) as well as Oladimeji, (2013) as follows;

$\mathrm{AE}=1+0.7\left(\mathrm{~N}_{\text {1adult }}-1\right)+0.5 \mathrm{~N}_{\text {2children }}-------(1)$

Where, AE represents adult equivalent, 0.7 and 0.5 are constant representing consumption per adult equivalent, in order to capture differences in economies of scale and age of bee farmers respectively, $\mathrm{N}_{1}$ represents the number of adult aged 15 and above and $\mathrm{N}_{2}$ is the number of children aged less than 15.

Logit model was selected for this study largely due to its simplicity of calculation. Moreover, its probability approaches zero at a slower rate as the value of explanatory variable gets smaller and smaller and the probability approaches 1 at a slower and slower rate as the value of the explanatory gets larger and larger (Gujarati, 1988 in Oladimeji, 2013). The probability that a bee farmers will fall below the poverty was postulated as a function of socioeconomic and institutional characteristics. Therefore, The underlying response variable $y^{*}$ in the case of binary choice was econometrically specified by the multivariate logit regression relation:

$\mathrm{P}_{1}=\mathrm{y}^{*}=\mathrm{F}(\mathrm{Z})=\mathrm{F}(\gamma+\Sigma \lambda 1 X 1)=\frac{1}{1+e^{-Z_{1}}}$

Where: $P_{i}=$, that is, the probability that a bee farmers will fall below the poverty line, ranges from 0 to $1 ; 1=$
If household had at least $2 / 3$ of mean total bee income/year (\#), and

$0=$ If household had less than $2 / 3$ of mean total bee income/year ( $\#$,

$\mathrm{F}=$ the cumulative distribution function for $\mu_{\mathrm{i}}$,

$\mathrm{e}=$ the base of natural logarithms which is approximately equal to 2.718 ,

$Z_{i}=$ is the function of a vector of $n$ explanatory variables and expressed as:

$Z_{i}=\beta_{0}+\Sigma \beta_{i} X_{i}, \quad \mathrm{i}=1,2, \ldots . ., 9$------

$=$ intercept; $\beta \mathrm{i}=$ vector of unknown coefficients and $X_{i}$ $=$ the $i^{\text {th }}$ explanatory variables.

Hosmer and Lemeshow (1989) and Oladimeji, (2013) pointed out that the Logit Model could be written in terms of the odds and log of odds which enables one to understand the coefficients. The odds ratio implies the ratio of the probability $\left(\mathrm{P}_{\mathrm{i}}\right)$ and the probability that $\mathrm{i}$ bee farmer will fall below the poverty and, $\left(1-\mathrm{P}_{\mathrm{i}}\right)$ implies that $\mathrm{i}$ bee farmer is not poor, that is

$$
P_{i}=\frac{1}{1+e^{-Z_{1}}}
$$

Thus, if the stochastic disturbance term is taken into account, the logistic model becomes: $Z_{i}=\beta_{0}+\beta_{i} X_{i}+\beta_{2} X_{2}+\ldots \ldots \ldots \ldots .+\beta_{9} X_{9}+u_{i}$ ------5)

$\mathrm{X}_{\mathrm{i}} \mathrm{S}$ are estimated by maximum likelihood method. The definition of the independent variables included in the logistic regression in equations 3 and 5 are as follows: $\mathrm{X}_{1}=$ Bee farming experience (years); $\mathrm{X}_{2}=$ Education (years of formal schooling); $X_{3}=$ Adjusted household size measured by OECD scale in equation $1 ; X_{4}=$ Number of hives owned by bee farmers; $X_{5}=$ Membership of cooperative of bee farmers (years); $X_{6}=$ Access to extension contacts on bee farming activities; $\mathrm{X}_{7}=$ Amount of credit available for bee farming activities (\#); $X_{8}=$ Bee farming income ( $\#$ ) and $X_{9}=$ Non- bee income (\#).

In capturing the degree of poverty among the bee farmers, a Foster-Greer-Thorbecke (FGT) index was used to describe influence of output, credit, level of education attainment and modern techniques on welfare of bee farmers given in equation 6 as:

$$
p_{a i}=\frac{i}{n} \sum_{i=1}^{q}\left(\frac{z-y_{i}}{z}\right)^{a}
$$

Where: is the poverty index for the $\mathrm{i}^{\text {th }}$ sub-groups, $\mathrm{n}$ is the total number of households, $Y_{i}$ is the per adult equivalent income or expenditure of $i$-th household, $z$ is the poverty line, $\mathrm{q}$ is the number of the sampled household population below the poverty line and is the aversion to poverty it ranges from 0 to 2 (Foster et al., 1984). It is important to test whether the sub-group of ranking above is robust to the choice of the poverty line. The test of robustness of poverty line was carried out by plotting the Cumulative Distribution Functions (CDF) of the two groups against the specified range of poverty line, varied at $70 \%-145 \%$. The horizontal axis shows the range of poverty line in monetary value ( $\# /$ year) while vertical axis shows the cumulative percent of the proportion of the poor households.If the distribution of one lies below the other within varied poverty line, it shows that the choice of poverty line within the range will make no difference to the outcome. 
It implies that the poverty ranking of the two distribution functions in relation to the proportion of the poor is robust to all possible lines. The subgroups with lower CDF will have lower poverty depth and severity than sub-group with higher CDF (World Bank, 2005; Kyaw and Routray, 2006).

\section{RESULTS AND DISCUSSION}

\section{Descriptive Socio-economic Characteristics}

Analysis of summary of socio-economic and institutional variables of bee farmers is presented in Table 1. Results revealed that bee farming household heads in the study area are males dominated (96\%); average bee experience and cooperative membership of 18.5 years and about 8 years respectively with welfare.

Table 1: Definition and dominance indicators of the variables used in the Logit Model

\begin{tabular}{|c|c|c|c|c|}
\hline Variables description & Dominance indicators & Mean & Std dv & a priori \\
\hline Gender & About $96 \%$ were males & na & na & \\
\hline Bee experience (years) & About $52 \%$ had up to 15 years & 18.5 & 4.9 & negative \\
\hline Level of education (years) & $54 \%$ had primary or $>$ schooling & 6.2 & 2.7 & negative \\
\hline Adjusted household size & $62 \%$ had size of $6-9$ & 6.0 & 2.1 & positive \\
\hline Number of hives & $69 \%$ had average of 36 hives & 31 & 10.3 & negative \\
\hline Cooperative (years) & $56 \%$ did not participate & 7.6 & 4.5 & negative \\
\hline Extension (contacts) & $94 \%$ had no extension contacts & 0.45 & 0.09 & negative \\
\hline Subsidiary occupations & $75 \%$ engage in arable farming & na & na & - \\
\hline Access to credit (\#) & $87 \%$, no access to formal credit & 5400 & 1720 & negative \\
\hline Bee income (\#) & $65 \%$ earned $>\# 32,000 /$ season & 30800 & 12200 & negative \\
\hline Non-bee income ( & $67 \%$ had $>25,000 /$ year & 35600 & 16450 & negative \\
\hline Expenditure/ adult (\#) & $51 \%$ above $2 / 3$ monthly & \multicolumn{3}{|c|}{ dependent variable } \\
\hline
\end{tabular}

Source: Field survey, 2012

Majority of the pooled farmers $(75 \%)$ had subsidiary occupations with average yearly off-farm income of $\# 35,600$. This shows that the rural farmers have developed capacity to cope with increasing vulnerability associated with apicultural practices such as diversification and migration. Further analysis revealed that $65 \%$ of the apiculturists inherited the farmland, $20 \%$ rented the land while $15 \%$ purchased the land. Kenya top bars hive were used by $58 \%$, $15 \%$ used langsroth and $27 \%$ used other type of hives. Traditional method of beekeeping was used by $31 \%$, while $69 \%$ used modern method of beekeeping. This study shows that most beekeepers in the study area $(70 \%)$ combined arable farming and apiculture as their main occupation while $30 \%$ choose apiculture as secondary occupation. The study is comparable with findings of Abdulai and Abubakari, (2012); Abere and Lameed (2012); Ajao and Oladimeji, (2013) who reported apiculture as common secondary occupation with a ranged of 20$80 \%$ among arable farmers in the tropical areas.

\section{Determinant of poverty among the bee farming households}

The logit regression result of the determinant of poverty among the bee farmers is shown in Table 2 . The generalized likelihood ratio statistics was 76.21 exceeds the critical chi-square values at $1 \%$ level of significance; the Pseudo $\mathrm{R}^{2}$ of 0.430 and the LR (Chisquare) of 32.05 implies that the overall model is fitted and the explanatory variables used in the model were collectively able to explain the correlates mean household size of 7 and adjusted size of 6 which is in conformity with previous finding by Ajao and Oladimeji, (2013). The estimated mean years of schooling of bee farmers were 6.2 years, skewed towards minimum education and above 2011 UNDP mean education index of 5 years for Nigeria. Although this reflects a low level of education for bee farmers but previous studies in the studied area by Oladimeji and Abdulsalam, (2013) estimated lower value among rice farmers in Kwara State. $65 \%$ of bee farmers earned at least \#32,000 per annum each and average income of bee pooled farmers of \#30,800. This shows positive contribution to bee farmers household's of poverty among the bee farming households in the study area. The results also revealed that years of bee farming experience $\left(X_{1}\right)$; level of education and training $\left(X_{2}\right)$; adjusted household size $\left(X_{3}\right)$; number of hives invested $\left(X_{4}\right)$; bee income $\left(X_{8}\right)$ and non-bee income $\left(X_{9}\right)$ were the most important significant variables in poverty determinants of bee farmers. The results also depict that bee farming experience $\left(X_{1}\right)$; number of hives invested $\left(X_{4}\right)$ and non-bee income $\left(X_{9}\right)$ were in line with postulate economic theory, carried expected signs and were all statistically significant at $1 \%$.

However, education $\left(X_{2}\right)$ and income realized from bee $\left(X_{8}\right)$ venture were statistically significant at $5 \%$ household size $\left(X_{3}\right)$ was marginally significant at $10 \%$ and carried unexpected sign. It suffice to note that membership of cooperative $\left(X_{5}\right)$, extension contacts $\left(X_{6}\right)$ and amount of credit accessed $\left(X_{7}\right)$ were statistically insignificant and not in line with a priori expectations. The estimated parameter of bee farming experience, $X_{1}(-0.401)$; level of education, $\left(X_{2}\right)(-0.099)$ and number hives invested, $X_{4}(-0.840)$ suggests that a unit increase in each of these variable will reduce poverty level by their estimated coefficients. The report is similar to findings by Abdulai and Abubakari, (2012); Abere and Lameed (2012); Ajao and Oladimeji, (2013) who confirmed in their studies that the independent variables fitted in this study plays a significant role in poverty reduction among bee farming households. and bear expected negative signs, but adjusted 
Table 2: Maximum likelihood estimation of the logit model for artisanal fishing poverty

\begin{tabular}{llll}
\hline Variables & Co-efficients & SE & t-value \\
\hline Bee experience $\left(\mathrm{X}_{1}\right)$ & $-0.401^{* * *}$ & 0.117 & -3.414 \\
Education $\left(\mathrm{X}_{2}\right)$ & $-0.099 * *$ & 0.050 & -1.997 \\
Adjusted household size $\left(\mathrm{X}_{3}\right)$ & $0.152^{*}$ & 0.087 & 1.738 \\
No of hives invested $\left(\mathrm{X}_{4}\right)$ & $-0.840 * * *$ & 0.097 & -8.620 \\
Cooperative membership $\left(\mathrm{X}_{5}\right)$ & 0.220 & 0.484 & 0.455 \\
Extension contacts $\left(\mathrm{X}_{6}\right)$ & -0.005 & 0.144 & -0.036 \\
Credit accessed $\left(\mathrm{X}_{7}\right)$ & 0.346 & 0.223 & 1.551 \\
Bee income $\left(\mathrm{X}_{8}\right)$ & $-0.598^{* *}$ & 0.279 & -2.147 \\
Non-bee income $\left(\mathrm{X}_{9}\right)$ & $-0.731^{* * *}$ & 0.149 & -4.900 \\
Constant & $1.098^{*}$ & 0.563 & 1.952 \\
No of observation $(\mathrm{n})$ & 80 & & \\
Log likelihood & 76.21 & & \\
Log Ratio Chi ${ }^{2}$ test & 32.05 & & \\
Prob. $>$ Chi & 0.0000 & & \\
Pseudo $\mathrm{R}^{2}$ & 0.430 & & \\
Adjusted $\mathrm{R}^{-2}$ & 0.372 & & \\
\hline
\end{tabular}

Source: logit regression result, $2012 ; * * * ; * * ; *$ significant at $1 \%, 5 \% \& 10 \%$ respectively

Further, bee income $\left(X_{8}\right)$ and non-bee income $\left(X_{9}\right)$ also portray improve welfare and apparently reduce poverty.

\section{Poverty Profile of Bee Farming Households}

The results of the poverty indices of the rural bee households in the study are presented in Table 3. Assuming household adjustment as specified in equation 1 , about $51 \%$ of the total population was living below the poverty line estimate of $\$ 236.50$ (US\$1.48) per household head per day. The household size adjustment and the scale economy were taken into consideration in line with World Bank, (2005) as ignoring household size will overestimate poverty of farmers with children, and underestimate the households without dependant(s).

Based on United Nation (UN), (2001), the most important purpose of poverty studies is to decompose socio-economic, institutional and infrastructural (living conditions) variables. This enabled comparison among sub groups so as to develop appropriate interventions to reduce poverty in the study area. Table 3 presents decomposition of bee farming households based on socio-economic and institutional characteristics. For example, poverty incidence was prevalent (36.3\%) among bee farming households without formal schooling as against approximately $11 \%$ for farmers who attended primary school, and only $2.5 \%$ for respondents who had a minimum of secondary education. Therefore, it can be concluded that average years of schooling of bee farmers were inversely related to their poverty status. Households with educated members were more liable to adopt new technology than their illiterate counterparts which may account for low poverty incidence among educated bee farmers.

Figure 3 presents the Cumulative Distribution Function for years of education attainment by bee farmers. The CDF of households with 12 years and above of formal education lay completely below those households with heads having no formal education and those with less than 6 years education. This implies that households with no formal education and with less than 6 years education would always be poorer than those sub-groups of households with 12 years and above of formal education within the specified range of poverty line.
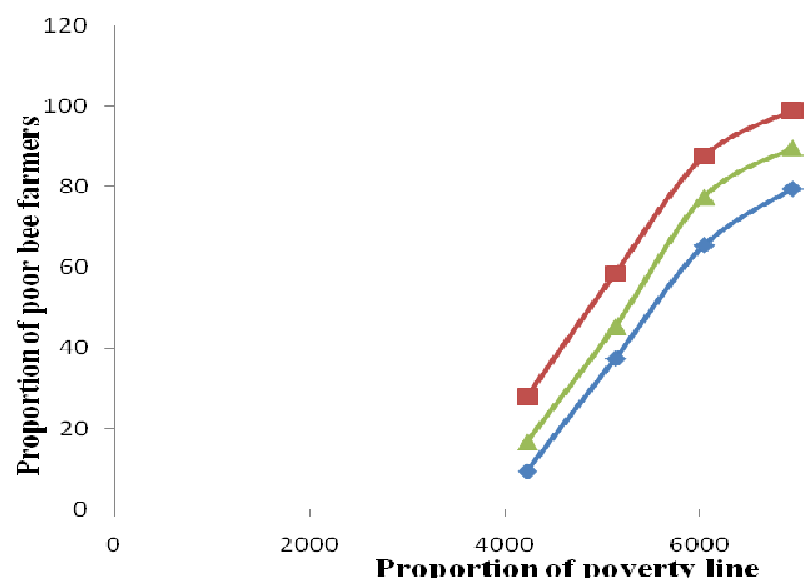

Level of Education

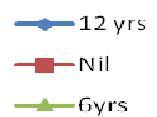

Figure 3: Distribution by years of Schooling of Household Heads

Similarly, the incidence of poverty was about $46 \%$ for all farming households without access to credit in Table 3 while the headcount for the bee households who utilized at least 200,000 amount to only $1.3 \%$. This is who utilized credit were below those without credit. This implied that households with credit are likely to have improved welfare compared to those with no access to credit. 
Table 3: Identified Poverty Sub-groups based on Socioeconomic Characteristics

\begin{tabular}{|c|c|c|c|c|c|c|}
\hline \multirow[t]{2}{*}{ Variables } & \multirow[t]{2}{*}{$\mathbf{P o}_{0}$} & \multirow[t]{2}{*}{$\mathbf{P}_{1}$} & \multirow[t]{2}{*}{$\mathbf{P}_{\mathbf{2}}$} & \multirow[t]{2}{*}{$\mathbf{n}$} & \multicolumn{2}{|c|}{ Share of poverty (po) } \\
\hline & & & & & $\mathbf{Q}$ & $\%$ \\
\hline \multicolumn{7}{|l|}{ Education } \\
\hline No education & 0.363 & 0.095 & 0.003 & 37 & 29 & 72.5 \\
\hline 6 years & 0.113 & 0.062 & 0.001 & 30 & 9 & 22.5 \\
\hline $\begin{array}{l}12 \text { \& above years } \\
\text { Level of Credit ( } \$ \text { ) }\end{array}$ & 0.025 & 0.004 & 0.000 & 13 & 2 & 5.0 \\
\hline Nil & 0.463 & 0.074 & 0.003 & 70 & 37 & 92.5 \\
\hline$<200,000$ & 0.025 & 0.001 & 0.000 & 6 & 2 & 5.0 \\
\hline $\begin{array}{l}>200,000 \\
\text { Hives invested }\end{array}$ & 0.016 & 0.000 & 0.000 & 4 & 1 & 2.5 \\
\hline Traditional hive & 0.275 & 0.053 & 0.002 & 25 & 22 & 55.0 \\
\hline Modern hive & 0.225 & 0.001 & 0.000 & 55 & 18 & 45.0 \\
\hline
\end{tabular}

Field survey, 2012; $P_{o}, P_{1}, P_{2}$ is the headcount, poverty gap \& squared poverty gap indices

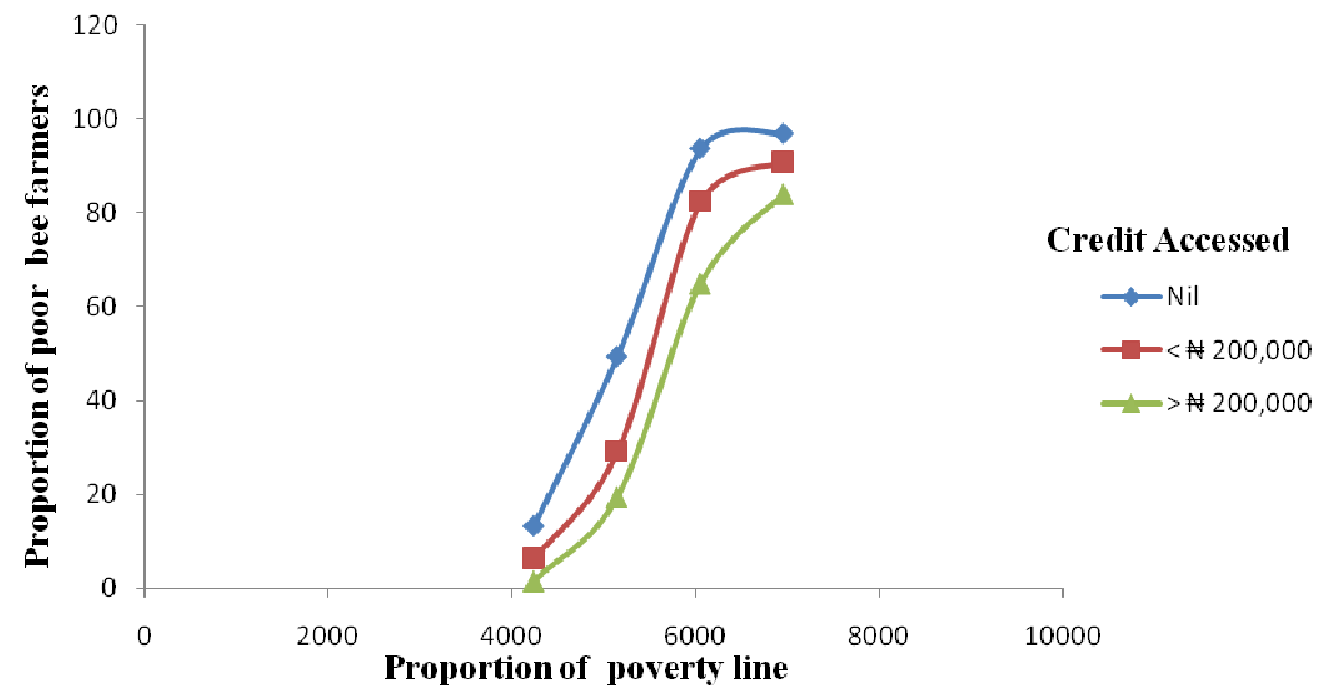

Figure 4: Cumulative distribution of credit accessed by bee farmers

All the possible pairs of the education attainment categories as well as that of adjusted household size have their poverty incidences, gaps and severity statistically significant different from one another either at $1 \%, 5 \%$ or at least $10 \%$ as depict in Table 4. This implied that both education attainment and adjusted household sizes affects the level of poverty incidence, gaps and severity.

Table 4: Test of significant of pair of Socio-economic variables

\begin{tabular}{llll}
\hline Education attainment (years) & $\mathbf{P _ { 0 }}$ & $\mathbf{P}_{\mathbf{1}}$ & $\mathbf{P}_{\mathbf{2}}$ \\
\hline 0 versus 6 & $-6.214 * * *$ & $-1.672^{*}$ & -1.603 \\
0 versus 12 & $-11.956 * * *$ & $-4.712 * * *$ & $1.721^{*}$ \\
6 versus 12 & $-1.940 *$ & $-1.792 *$ & 1.032 \\
Adjusted household size & & & \\
$1-4$ versus 5- 8 & $-2.061 * *$ & $-1.672 *$ & -1.603 \\
$1-4$ versus 9 \& above & $6.748 * * *$ & $-1.965 * *$ & $-1.721 *$ \\
5- 8 versus 9 \& above & $-2.415 * *$ & 1.261 & 1.062 \\
\hline Field survey, 2012; ***; **; $*$ significant at 1\%; 5\% \& 10\% & &
\end{tabular}

Table 5 presents the profile of the poverty status of the rural bee households based on living conditions. There was prevalence of poverty among bee households that utilized open spaces for disposing their faeces. The use of open spaces for faeces disposal however has negative implication on water pollution and health hazards for the households. Several studies such as World Bank, (2005); Olorunsanya and Omotesho, (2011), Oladimeji et al. (2014) also observed that farmers that construct and utilizes pit toilet will always maintained a better standard of living compare to households that utilizes open toilet facilities.

The households that utilized either well water or borehole had the lowest incidence of poverty of either $10 \%$ or $2.5 \%$ compare to the households that utilized stream water who recorded the highest figure (38\%) for the headcount index. Rural households in the study area had low income and barely lived above subsistence. Acquisition of modern water facilities required fund which might not be readily available to the rural households. 
For example, it costs between $\$ 20000$ and $\$ 50000$ (US\$125-US\$313) to dig and complete a well water and a minimum of not less than N200 000(US\$1250) to sink a borehole (KWADP/UNICEF, 2012). This resulted in the use of stream water with possible negative effect on their health status. Further, $41.3 \%$ of bee households that utilized local lamp for lightening were poor while only $1.3 \%$ of the households that utilized electricity were poor. Therefore, bee farmers that had access to and utilize modern sources of energy such as electricity for lightening is an indication of higher level of wellbeing for the bee farmers' household.

Table 5: Identified Poverty Sub-groups based on Institutional infrastructures

\begin{tabular}{|c|c|c|c|c|c|c|}
\hline $\begin{array}{l}\text { Variables } \\
\text { Toilet Facilities }\end{array}$ & $\mathbf{P}_{0}$ & $\mathbf{P}_{1}$ & $\mathbf{P}_{2}$ & $\mathbf{n}$ & \multicolumn{2}{|c|}{ Share of poverty } \\
\hline Open Field & 0.475 & 0.025 & 0.000 & 63 & 38 & 95.0 \\
\hline Pit Toilet & 0.025 & 0.001 & 0.000 & 17 & 2 & 5.0 \\
\hline \multicolumn{7}{|l|}{ Source of Water } \\
\hline Stream & 0.375 & 0.002 & 0.001 & 46 & 30 & 75.0 \\
\hline Well & 0.100 & 0.000 & 0.000 & 26 & 8 & 20.0 \\
\hline Others & 0.025 & 0.001 & 0.000 & 8 & 2 & 5.0 \\
\hline \multicolumn{7}{|l|}{ Source of Light } \\
\hline Local lamp & 0.413 & 0.002 & 0.001 & 39 & 33 & 82.5 \\
\hline Kerosene & 0.075 & 0.001 & 0.000 & 19 & 6 & 15.0 \\
\hline Electricity & 0.013 & 0.000 & 0.000 & 22 & 1 & 2.5 \\
\hline
\end{tabular}

Source: field survey, 2012

\section{Conclusion}

It may be concluded that poverty level among the bee farmers was high and that socio-economic, institutional and living conditions were the most important factors influencing poverty status of bee farmers in the study area. This implies that effort should be gear towards improving the trio-micro variables to improve the welfares and living standard, and reduce poverty level of the bee farmers. This will also be an impetus to the transformation of the bee production from subsistence to commercial production, to achieve the first Millennium goals of half the percentage of people in extreme poverty and hunger, and the seventh goal of ensuring environmental sustainable development policy of global objective.

\section{REFERENCES}

Abdulai, A. and Abubakari, M. (2012). Technical efficiency of beekeeping farmers in Tolonkumbungu district of Northern region of Ghana. Journal of Development and Agricultural Economics, 4(11):304-310.

Abere, S. A. and Lameed, G. A. (2012). Production and profitability of honey in Yewa North, Nigeria. Mediterranean Journal of Social Sciences, 3 (15): 182-187.

Ajao, A. M. (2012). Comparative studies on ecology and morphometrics of reared and feral honeybees in geological ones of Kwara State, Nigeria. Phd Thesis. Federal University of Agriculture, Abeokuta.

Ajao, A.M. and Oladimeji, Y. U. (2013). Assessment of contribution of apicultural practices to household income and poverty alleviation in Kwara State, International Journal of Science and Nature, 4(4): 687-698.

Bogale, A., Hagedorn, K. and Korf, B. (2005). Determinants of poverty in rural Ethiopia.

\section{Recommendations}

Based on the findings of this study, it is recommended that bee farmers should be encouraged by extension agents through their social organisations to imbibe modern technology, and should have access to improve toilet, potable water, affordable electricity and housing. Therefore, government at all level should pursue participatory community approach policy that will provide the needed infrastructures, credit facilities and training that will propel the farmers out of poverty. Ultimately, it will assist them in honey production, processing and marketing of their commodities so as to earn more income that will improve their living standards and apparently reduced poverty.

Quarterly Journal of International Agriculture, 44(2): 101-120.

Etim, N. A. and Ukoha, O. O. (2010). Analysis of poverty profile of rural households: evidence from South-South Nigeria. Journal of Agriculture and Soc. Sci., 6:48-52.

Food and Agriculture Organization (FAO), (2013). FAO Country Programming Framework (CPF) Federal Republic of Nigeria, Fiat Panis, Pp 141.

Foster, J. J., Greer, J. and Thorbecke, E. (1984). A Class of decomposable poverty measures. Econometrica, 52: 761-765.

Gujarati, D. (1988). Basic Econometrics. 2nd Edition, McGraw Hill Book Company, NY.

Hosmer, D. W. and Lemeshow, S. (1989). Applied Logistic Regression. Wiley -Interscience Publication, New York, USA.

Kyaw, D. And Routray, J. K. (2006). Gender and rural poverty in Myanmar. A micro level study in the dry zone. Journal of Agriculture and Rural Development in the Tropics and SubTropics, 107(2): 103-114. 
Kwara Agricultural Development Project (KWADP), (2008). House Journal and Bulletin, July, 2008.

Kwara Agricultural Development Project (KWADP/UNICEF), (2012). Information on water management. Quarterly reports.

National Bureau of Statistics (NBS), (2013). Poverty profile for Nigeria. Annual Report, Federal Republic of Nigeria.

National Population Commission (NPC), (2006). Population Census of the Federal Republic of Nigeria. Analytical Report at the NPC, Abuja, Nigeria.

Oladimeji, Y.U. (2013). Analysis of poverty and welfare measures among artisanal fishermen in Asa and Patigi fishing settlements of Kwara State, Nigeria. Research Journal of Agricultural Sciences, 4(5/6):594-601.

Oladimeji, Y.U. and Abdulsalam, Z. (2013) Analysis of technical efficiency and its determinants among small scale rice farmers in Patigi LGA of Kwara State, Nigeria. IQSR Journal of Agriculture and Veterinary Science, 3(3) Pp 34-39.

Oladimejl, Y.U., Damisa, M.A., Abdulsalam, Z. And Omokore, D.F. (2014). A micro level analysis of poverty among artisanal rural fishery in Kwara State, Nigeria, Ethiopian Journal of Environmental Studies \& Management, 7(4): 423-433.
Olorunsanya, E. O. and Omotesho, O. A. (2011). A gender analysis of poverty profile of rural farming households in North Central, Nigeria. International Journal of Agricultural Economics and Rural Development, 4(2): 11-27.

Ravallion, M. (1998). Reaching poor areas in a federal system. Working papers: poverty, income distribution, safety nets, micro-credit, World Bank, Washington D.C. USA.

Resources Inventory and Management (RIM), (1992). Federal Ministry of Agriculture and Natural Resources, Livestock data, Livestock resources division, annual reports.

UN (United Nations), (2001). Indicators of sustainable development: guidelines and methodologies. United Nations, New York.

United Nations Development Program (UNDP), (2009). Human Development Report, Nigeria, 2008-2009. Achieving growth with equity, UNDP Publications.

World Bank, (2005). Introduction to poverty analysis. Poverty manual, All, JH Revision.

World Bank, (2011). World development indicator, Human Development Index Report, New York. Oxford University Press. 